\title{
The nutritional requirements of the protein-depleted chicken
}

\author{
6.* Amino acid requirements for repletion of \\ adult cocks depleted by starvation $\dagger$ \\ By JACOBUS P. H. WESSELS AND HANS FISHER \\ Nutrition Laboratories, Department of Animal Sciences, Rutgers, \\ The State University, New Brunswick, New fersey, USA
}

(Received I6 fune 1964-Accepted 1o October 1964)

The protein and amino acid requirements of protein-depleted animals and man have received but scant attention and it continues to be the practice to apply to depleted subjects the requirement standards for normal, non-depleted subjects (Scrimshaw, Bressani, Béhar \& Viteri, 1958; Waterlow, Cravioto \& Stephen, 1960). Earlier reports in this series showed unequivocally that variously protein-depleted growing chickens had, in comparison with normally growing chickens, a greater protein requirement and an altered amino acid requirement (Summers \& Fisher, 1960, 1962a). Adult animals or man do not appear to be subjected to the proteindeficiency diseases that affect growing animals and children (Keys, Brožek, Henschel, Mickelsen \& Taylor, 1950; Allison \& Fitzpatrick, 1960). This may well be a reflection of the buffering activity of protein reserves (Wessels \& Fisher, 1965) and of the 'particulate' rather than 'aggregate' nature of the amino acid requirement of adults (Fisher, Brush, Shapiro, Wessels, Berdanier, Griminger \& Sostman, 1963).

In view of these differences between growing and adult animals it appeared important to study certain amino acid requirements of adult cocks protein-depleted by starvation beyond the loss of their protein reserves. The requirements for histidine, arginine and tryptophan were investigated and compared with similar estimates of requirements for maintenance of normal, non-depleted cocks as determined earlier in this laboratory (Leveille \& Fisher, I958). The choice of the amino acids studied was based on the following: $(a)$ the normal, non-depleted adult cock does not require histidine for maintenance; $(b)$ the arginine requirement of the normal adult cock represents the highest requirement for any single essential amino acid; and $(c)$ the tryptophan requirement of the normal adult cock represents a low quantitative need for an amino acid. For these reasons we considered changes in requirements for these amino acids to be representative of changes in any of the other essential amino acids.

* Paper no. 5: Z. Ernährungsw. (1962), 3, 48.

$\uparrow$ Paper of the Journal Series, New Jersey Agricultural Experiment Station, Rutgers, The State University of New Jersey, Department of Animal Sciences, New Brunswick. Supported in part by Grants-in-Aid from The National Science Foundation and US Public Health A-4904. 


\section{EXPERIMEN'TAL}

The techniques used in determining the amino acid requirements of proteindepleted adult cocks were similar to those employed by Leveille \& Fisher (1958) in their studies with non-depleted animals.

Plan. The individual amino acid requirements were determined in two ways: First, progressively lower levels of the amino acid under study were given in the diet until the lowest level at which maximum retention would be maintained was established. Then, in a second phase, which included two experiments ( $A$ and $B$ ), the requirements were studied in other, newly protein-depleted cocks given levels of amino acid that appeared adequate from the results of the first study. Each amino acid level in this second phase was studied with a separate group of depleted cocks.

Table I. Bleeding schedule of four protein-depleted cocks used in the study of histidine requirement, showing the amount of blood removed and haematocrit values

$\begin{array}{ccc}\begin{array}{c}\text { Day of } \\ \text { experimental } \\ \text { period* }\end{array} & \begin{array}{c}\text { Amount of } \\ \text { blood removed } \\ \text { (ml/bird) }\end{array} & \begin{array}{c}\text { Haematocrit } \dagger \\ (\%)\end{array} \\ \text { I } & 6 \cdot 0 & 46.7 \pm 1 \cdot 8 \\ 3 & 6 \cdot 5 & 39.3 \pm 0 \cdot 5 \\ 6 & 10.5 & 32 \cdot 5 \pm 0 \cdot 3 \\ 9 & 8 \cdot 0 & 31 \cdot 4 \pm 0 \cdot 2 \\ 16 & 6.5 \ddagger & 32 \cdot 2 \pm 0.47\end{array}$

* The $\mathrm{N}$ balance and food refusal values for these cocks, depleted by prior starvation and by bleeding during the experimental period, appear in Table 4 .

$\dagger$ Mean value with its standard error.

$\ddagger$ For two of the four cocks only. The $\mathrm{N}$ balance of the other two had decreased to such an extent and they appeared so anaemic that further bleeding seemed inadvisable.

Protein depletion was induced by starvation rather than by giving a protein-free diet. With the use of the latter procedure, such a long depletion period was necessary that the cocks often refused to eat any of the diets offered both during and after the depletion. For the studies now described most cocks were starved for approximately Io days followed by a few days on a protein-free diet.

For the first part of the requirement studies, each of four protein-depleted cocks was successively given diets containing decreasing levels of L-tryptophan and Larginine hydrochloride. Histidine (given as L-histidine hydrochloride monohydrate) requirements were studied with three cocks protein-depleted as before, and with four additional cocks that had been protein-depleted by starvation as well as by bleeding from the wing vein. The bleeding schedule, showing the amount of blood removed, is given in Table I together with haematocrit values. During this first phase of the study (presented in Tables 3 and 4 ), the depletion period with different levels of the amino acids varied with the nature of the $\mathrm{N}$ balance response obtained.

During trials A and B of phase 2, groups of from two to five protein-depleted cocks were each given diets containing levels of amino acids near those indicated as meeting the requirement by the results of the first study.

Animals. Mature White Leghorn cocks were used in all experiments. Those used 
for the first part of the requirement studies were starved for 10 days and then given a protein-free diet ad lib. for 3 days. The mean body-weight loss during this depletion period was $24 \%$. For trial $A$ of the second phase, some of the cocks were starved for 8 days and then given a protein-free diet ad lib. for 2 days. During this ro-day depletion period, they lost $13 \%$ of their initial, predepletion body-weight. Four additional cocks that had been used during the first part of the requirement studies were partly repleted on a complete diet (maize-soya, $15 \%$ protein), then starved for 5 days followed by 2 days on the protein-free diet. These cocks had lost $17 \%$ of their initial, predepletion body-weights. For trial B the cocks were starved for 7 days followed by 2 days on a protein-free diet. These birds lost $19 \%$ of their initial bodyweights. In view of the $\mathrm{N}$ losses observed during similar depletion regimens by Summers \& Fisher $(1962 b)$, it was safe to assume that the cocks used in the studies now presented had been depleted of body $\mathrm{N}$ beyond their protein reserves (Wessels \& Fisher, 1965).

Table 2. Percentage composition of basal diet and of amino acid mixture used in studies with protein-depleted cocks

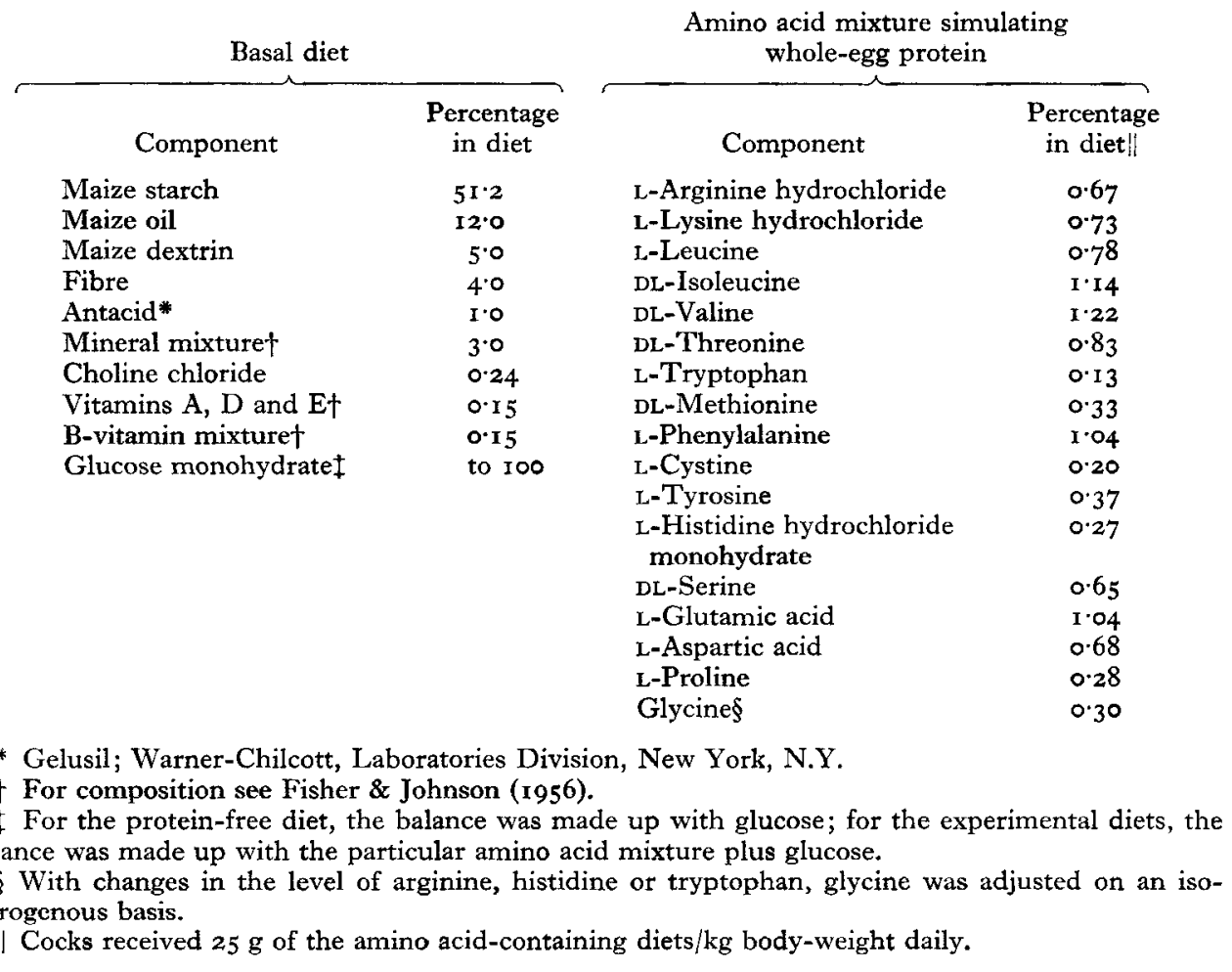

Diets. A synthetic diet was used in which the amino acids were supplied in a mixture patterned after the composition of whole-egg protein (Table 2). $\mathrm{N}$ was provided in all diets at $284 \mathrm{mg} / \mathrm{kg}$ undepleted body-weight daily and, when the level of an essential amino acid was reduced, glycine was substituted isonitrogenously. The level of $284 \mathrm{mg} \mathrm{N} / \mathrm{kg}$ body-weight daily has proved adequate to maintain adult cocks 
in $\mathrm{N}$ equilibrium (Leveille \& Fisher, 1958). A protein-free diet in amounts not exceeding $15 \mathrm{~g} / \mathrm{kg}$ body-weight daily, but dependent on the amount they initially consumed within $3 \mathrm{~h}$ after they had been given access to food, was offered to the cocks. No protein-free diet was offered, unless the amino acid-containing diet had been fully consumed. The composition of the protein-free diet is also shown in Table 2.

Procedure and analysis. All birds were housed in individual battery cages and given their diets in pelleted form. Excreta were collected continuously throughout the first phase of the requirement studies, and again continuously after a 3- to 5-day adjustment period during trials $A$ and $B$ (phase 2).

Excreta bulked for $48 \mathrm{~h}$ were homogenized with water and analysed for $\mathrm{N}$ by semi-micro-Kjeldahl digestion followed by the colorimetric determination of the ammonium ion on the AutoAnalyzer (Ferrari, 1960). Food N was determined in the same manner.

\section{RESULTS}

The results of the requirement studies appear in Tables $3-5$. The values in Tables 3 and 4 represent the repletion of depleted cocks on successively different levels of essential amino acids given in diets supplied at different stages during the period of repletion. It should be recognized that the rate of body $\mathrm{N}$ repletion was not constant and that a time lag occurred during its early stages.

Table 3. $N$ excretion and balance of protein-depleted cocks receiving different levels of arginine, tryptophan or histidine in their repletion diets

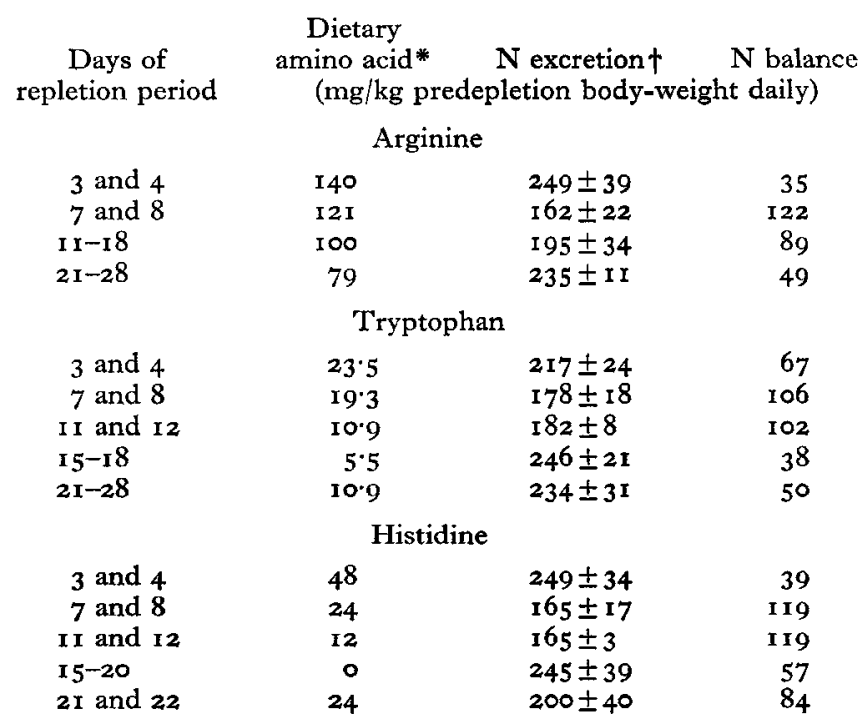

* Given in the diet as L-arginine hydrochloride, L-histidine hydrochloride monohydrate and Ltryptophan.

$\uparrow$ Mean values with their standard errors for three cocks on the histidine-containing diets and four cocks each on the arginine- and tryptophan-containing diets. Each group of animals received successively each of the amino acid levels indicated in the second column. 
Arginine. When studied with diets supplying decreasing levels of the amino acid (Table 3), the arginine requirement for repletion appeared to be satisfied by an amount between 100 and $12 \mathrm{I} \mathrm{mg} / \mathrm{kg}$ predepletion body-weight daily. When single

Table 4. Effect of different levels of histidine intake upon food consumption, $N$ excretion and balance of four cocks protein-depleted by starvation and bleeding*

Moderately depleted cocks $\dagger$

$\begin{array}{ccc}\text { Dietary } & \mathrm{N} & \mathrm{N} \\ \text { histidinef } & \text { excretion } & \text { balance }\end{array}$

Days of period

3 and 4

7 and 8

11 and 12

13 and 14

15 and $x 6$

17 and 18

19 and 20

21 and 22 (mg/kg predepletion body-weight daily)

$\begin{array}{ll}48 & 337 \\ 24 & 380 \\ 12 & 357 \\ 12 & 349 \\ 12 & 329 \\ 12 & 315 \\ 12 & 294 \\ 24 & 322\end{array}$

Severely depleted cocks†

\begin{tabular}{|c|c|c|}
\hline $\begin{array}{l}\text { Dietary } \\
\text { istidinef } \\
(\mathrm{mg}) \\
\text { bod }\end{array}$ & 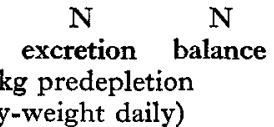 & $\begin{array}{c}\text { Food } \\
\text { refusal } \\
\% \text { offered }\end{array}$ \\
\hline
\end{tabular}

* The cocks were bled according to the schedule given in Table 2 .

+ The results are so grouped since the response of two cocks suggested that they had lost considerably more body $\mathrm{N}$ than did the other two.

$\ddagger$ Given as L-histidine hydrochloride monohydrate.

Table 5. $N$ excretion and balance of protein-depleted cocks measured during the period 6 th-9th day on repletion diets providing different levels of amino acids

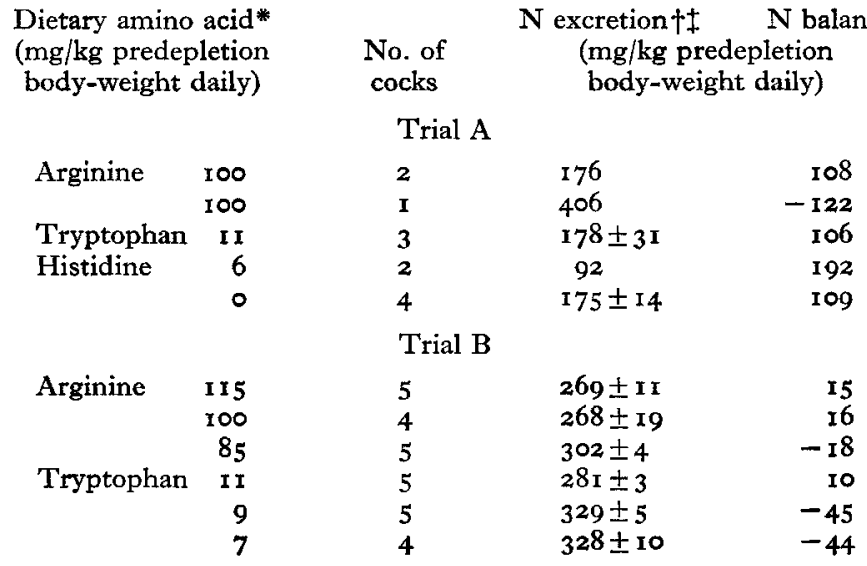

* Given in the diet as L-arginine hydrochloride, L-histidine hydrochloride monohydrate and Ltryptophan.

+ In trial A, excreta collections were made on the 6 th and 7 th days after the giving of the repletion diets; in trial B, collections were made from the 6th to 9th days inclusive; cocks used in trial $B$ were more severely depleted than those from trial $A$ (see p. 73).

$\ddagger$ Except for arginine and one histidine value in trial A, mean values with their standard errors.

levels of arginine were given to separate groups of newly depleted cocks (Table 5 ) the level of $100 \mathrm{mg}$ generally appeared adequate. However, as can also be seen in Table 5, one cock in trial A was in severe negative balance at this level of arginine intake. 
Tryptophan. The results in Table 3 clearly show a break in $\mathrm{N}$ balance when the dietary tryptophan level was decreased from 10.9 to $5.5 \mathrm{mg} / \mathrm{kg}$ predepletion bodyweight daily. The further requirement studies (trials $\mathrm{A}$ and $\mathrm{B}$, results given in Table 5) confirm a tryptophan requirement value of approximately I I $\mathrm{mg} / \mathrm{kg}$ predepletion body-weight daily. In trial $\mathrm{B}$, the $9 \mathrm{mg}$ level was unsatisfactory and the cocks receiving this amount of tryptophan were in negative $\mathrm{N}$ balance.

Histidine. When, during the repletion period, histidine was completely removed from the diet, $\mathrm{N}$ balance declined from 94 to $15 \mathrm{mg} / \mathrm{kg}$ predepletion body-weight daily, with a mean value of $57 \mathrm{mg}$ (Table 3 ) for the 15 - to 20 -day period. When cocks were additionally depleted by bleeding (haemoglobin is particularly rich in histidine), they showed a clear requirement for histidine (Table 4). Not only were two of the cocks in negative $\mathrm{N}$ balance on reduced histidine intakes, but all four birds refused to consume part of the diet offered. It would thus appear that a histidine deficiency could be demonstrated in severely protein-depleted cocks. In contrast to a histidine requirement as indicated by the results in Table 4 , the observations in Table 5 give no evidence of a need for this amino acid by a group of less severely depleted cocks.

\section{ISCUSSION}

One of the difficulties experienced in this investigation was the variable $\mathrm{N}$ loss during depletion periods of similar duration. Such variation, which in these experiments is evident only from the differences in rate of repletion, has been put on a quantitative basis by Summers \& Fisher $(1962 b)$. Among a group of ten proteindepleted cocks, three birds lost nearly twice as much $\mathrm{N}$ during $\mathrm{I} 2$ days of starvation as did the other seven. Since the rate of repletion is dependent upon the extent of depletion (Wessels \& Fisher, I965), it was not surprising to observe differences in $\mathrm{N}$ balance during the different phases of these studies dealing with the requirements for a single essential amino acid. It is nevertheless noteworthy that, despite marked differences in $\mathrm{N}$ retention (e.g. the values for corresponding levels of arginine in Tables 3 and 5 should be compared), the optimal dietary amino acid requirement was similar.

We should like to call attention to the fact that the amino acid levels given to the animals were calculated on the basis of predepletion body-weights. In view of the preceding discussion regarding the variability in the rate of $\mathrm{N}$ depletion, we considered the 'normal' body-weight an acceptable reference point as the basis for expressing amino acid intake and requirement, particularly since we had no basis for estimating the extent of protein depletion.

In this study we are primarily concerned with the requirements relative to one another for the three amino acids studied, rather than with absolute values. Viewed in this manner, it appears that the requirement pattern was not materially altered by depletion of body $\mathrm{N}$ beyond the protein reserves when compared with the pattern determined with undepleted mature cocks by Leveille \& Fisher (1958, 1959), and Leveille, Shapiro \& Fisher (1960). In a series of experiments unrelated to the studies now presented, twenty-one adult cocks protein-depleted by starvation showed no 
requirement for histidine. However, in the study now presented a requirement for histidine could be demonstrated after depletion also of haemoglobin, a histidine-rich protein (Table 4 ).

The essentially unchanged relative requirements for the three amino acids, arginine, histidine and tryptophan, as observed with adult cocks depleted by starvation, stand in marked contrast to the results obtained by Summers \& Fisher (1962a) with young chickens protein-depleted by starvation. The considerable resistance which the adult subject displays in the face of protein malnutrition may well be related to the smaller $\mathrm{N}$ loss experienced during depletion in comparison to that of the growing animal. Summers \& Fisher (1960) observed a $21 \%$ loss in carcass $\mathrm{N}$ in 12-day-old chickens during a 6-day starvation period, whereas these workers (1962b) observed a loss of only $12.5 \%$ body $\mathrm{N}$ in adult cocks during 12 days of starvation. When one considers that at least a portion of this $\mathrm{N}$ loss in the adult cock may be 'reserve protein' which can be repleted with dietary non-essential amino acid N (Wessels \& Fisher, I965), the finding of an essentially unaltered amino acid requirement pattern is not surprising.

The results in trial A (Table 5) indicate considerable variation in the arginine requirements inasmuch as one of three cocks was in strong negative balance on a level of arginine that was adequate for all other animals in this and the earlier trial (Table 3 ). Such variations in requirement appear to be peculiar to arginine. Griminger \& Fisher (1962) have reported on the heritable character of this variation in arginine requirement. The cocks used in the studies now presented had the same genetic background as those from which Griminger \& Fisher (I962) have selected and bred lines with high and with low requirements for arginine.

\section{SUMMARY}

I. White Leghorn cocks protein-depleted by starvation for a period of approximately io days followed by several days on a protein-free diet received, in succession, diets containing varying amounts of histidine, arginine and tryptophan to establish the lowest level of each of these amino acids that would permit $\mathrm{N}$ retention.

2. Histidine was found to be non-essential except for cocks very severely depleted of body $\mathrm{N}$ by repeated bleeding in addition to the starvation. Levels of approximately I00 $\mathrm{mg} \mathrm{L}$-arginine and of approximately I I $\mathrm{mg} \mathrm{L}$-tryptophan $/ \mathrm{kg}$ body-weight daily appeared adequate to enable two additional groups of protein-depleted cocks to retain $\mathrm{N}$.

3. In comparison with non-depleted adult cocks, the protein-depleted adult cocks did not show the same extent and degree of change in amino acid requirement that had previously been observed in protein-depleted as compared with non-depleted young chickens.

4. More variation in the response of protein-depleted cocks was encountered with varying levels of arginine than with the other amino acids studied. 


\section{REFERENCES}

Allison, J. B. \& Fitzpatrick, W. H. (1960). Dietary Proteins in Health and Disease. Springfield, Ill.: Charles C. Thomas.

Ferrari, A. (1960). Ann. N.Y. Acad. Sci. 87, 792.

Fisher, H., Brush, M. K., Shapiro, R., Wessels, J. P. H., Berdanier, C. D., Griminger, P. \& Sostman, E. R. (1963). F. Nutr. 8r, 230.

Fisher, H. \& Johnson, D. (1956). F. Nutr. 60, 26 r.

Griminger, P. \& Fisher, H. (1962). Proc. Sac. exp. Biol., N.Y., r1r, 754.

Keys, A., Brožek, J., Henschel, A., Mickelsen, O, \& Taylor, H. L. (1950). The Biology of Human Starvation. Minneapolis, Minnesota: University of Minnesota Press.

Leveille, G. A. \& Fisher, H. (1958). F. Nutr. 66, 441.

Leveille, G. A. \& Fisher, H. (1959). F. Nutr. 69, z89.

Leveille, G. A., Shapiro, R. \& Fisher, H. (1960). F. Nutr. 72, 8.

Scrimshaw, N. S., Bressani, R., Béhar, M. \& Viteri, F. (1958). F. Nutr. 66, 485.

Summers, J. D. \& Fisher, H. (1960). F. Nutr. 72, I 53.

Summers, J. D. \& Fisher, H. (196za). Z. Ernährungsw. 3, 40.

Summers, J. D. \& Fisher, H. (1962 b). Z. Ernährungsw. 3, 48.

Waterlow, J. C., Cravioto, J. \& Stephen, J. M. L. ( I960). Advanc. Protein Chem. 15, I31.

Wessels, J. P. H. \& Fisher, H. (1965). Brit. F. Nutr. 19, 57. 